\section{Impact of utilisation of internet services and resources on university lecturers' academic activities in Adamawa state, Nigeria}

\section{Tukur Abba}

Modibbo Adama University of Technology, Yola, Nigeria
Information Impact:

Journal of Information and Knowledge Management 2017, Vol. 8 (2) Pg. 19 - 32 ISSN: $2141-4297$ (print) ISSN: 2360 - 994X (e-version) www.informationimpact.org

\begin{abstract}
The study investigated the impact of utilisation of Internet services and resources on academic activities of university lecturers' in Adamawa State, Nigeria. This study is guided by two objectives, one research question and a single hypothesis. Survey research method was adopted to carry out research from Adamawa State University (ADSU) Mubi, American University of Nigeria (AUN), Yola and Modibbo Adama University of Technology, (MAUTECH) Yola. The population for the study consisted of 847 lecturers in the Universities. A sample of 265 respondents was drawn using the Krejcie and Morgan's (1970) table for determining sample size for a given population. Furthermore, stratified random sampling technique was used in selecting respondents for the study. The instrument used for data collection was a set of questionnaire. Data collected were analysed using descriptive statistics to answer the research question, while inferential statistics of Chi-square was used to test the formulated null hypothesis. Statistical Package for Social Sciences (SPSS) tool, version 20.0 was also used for the analysis. Results revealed that the level of utilisation of Internet services and resources was generally moderate. In addition, impact of utilisation of Internet services and resources was rated moderate. Based on the findings of this study, it was recommended among others, that there is the need for Universities to create more awareness and engage in sensitisation, demonstrations and training workshops on the use and benefits for academic activities. Lecturers should be encouraged to use Internet services and resources for collaboration with their colleagues for publication activities, especially online publications.
\end{abstract}

Key words: internet, utilisation, lecturers, universities, north-east.

\title{
Introduction
}

Literarily, Internet is described as global connections of computers of various sizes, capacity and functionality. These networks are often referred to as "information superhighways," where computers are interconnected with the sole purpose of providing services, resources and information across the globe, thus reducing the entire universe to a "global village." According to Madu (2008), the Internet is regarded as the largest global connections of computer network, making it the network of networks. Internet services and resources are commonly or basically used for the purposes of information, communication, education, research, recreation and entertainment among others. According to Eyitayo (2008) the Internet enables users' access to vast quantities of information and also communicates with 
one another globally. Kamba (2008) observed that the utilisation of Internet services for exchange of research has reduced shortage of information resources thereby bringing an increase in the output of research publications. Ogunjobi and Fagbami (2012) confirmed that Internet services and resources are capable of providing Nigerian researchers and scholars the enabling environment to overcome the barriers of communication and collaboration and also providing scholars, researchers, individuals and their organisations the advantages of presenting their research finding and ideas across the globe.

The impact of the Internet services and resources varied from country to country. As a tool to connect people with information, the Internet has now become a social networking vehicle that is changing the way people in all countries communicate with one another (Parent \& Cruickshark, 2009). The impact of Internet utilisation for teaching and research by academics in Ladoke Akintola University of Technology (LAUTECH) was studied by Ajala, Adegun and Oyewunmi (2010) the Internet was found to be useful for research activities, however it was not utilised for effective teaching and learning purposes. However, a study conducted in Makerere University School of Library and Information Science, Uganda, by Okello-Obura and Magara (2008) revealed the satisfactory benefits respondents derived from the utilisation of the various Internet services and resources. Bassi and Camble (2011) highlighted that in order to facilitate access to information by all users within the university system, the Federal Ministry of Education in 2000, introduced the virtual library project, which pulled together resources electronically, connecting all academic libraries in Nigeria with the hub at National Universities Commission (NUC). Consequently, university libraries in Adamawa State were not left behind in their efforts to providing electronic resources to their users'.

Al- Asmari (2005) conducted a study on the use of Internet services and resources by teachers in the Kingdom of Saudi Arabia. The study revealed low level of utilisation among faculty members. In the same vein, Adika (2003) reported low usage of Internet services and resources among university faculty members in Ghana. Dangani and Mohammed (2009) indicated that many academics in the Nigerian universities cannot use Internet and other ICT facilities very well. This study will therefore, investigate the level of Internet services and resources utilisation among the lecturers in the Universities in Adamawa State to reveal the impact of utilisation of Internet services and resources on their academic activities.

\section{Objectives of the study}

The objectives of the study were to determine the:

1. Extent of utilisation of Internet services and resources on university lecturers' academic activities in Adamawa State; and

2. Impact of utilisation of Internet services and resources on university lecturers' academic activities in Adamawa State. 


\section{Research question}

1. To what extent is the level of utilisation of Internet services and resources for university lecturers' academic activities in Adamawa State?

\section{Hypothesis}

H0: There is no significant difference in the impact of utilisation of internet services and resources, on academic activities of university lecturers' in Adamawa State.

\section{Theoretical framework}

This study was anchored on the Technology Acceptance Model (TAM) theory postulated by Davis (1989). The theory states that the success of a system can be determined by user acceptance of the system, measured by three factors: perceived usefulness (PU), perceived ease of use (PEOU), and attitude towards usage (ATU) of the system (as cited in Shroff, Deneen, \& Eugenia, 2011). According to TAM, one's actual use of a technology system is influenced directly or indirectly by the user's behavioral intentions, attitude, perceived usefulness of the system, and perceived ease of the system. TAM also proposes that external factors affect intention and actual use through mediated effects on perceived usefulness and perceived ease of use (Park, 2009).

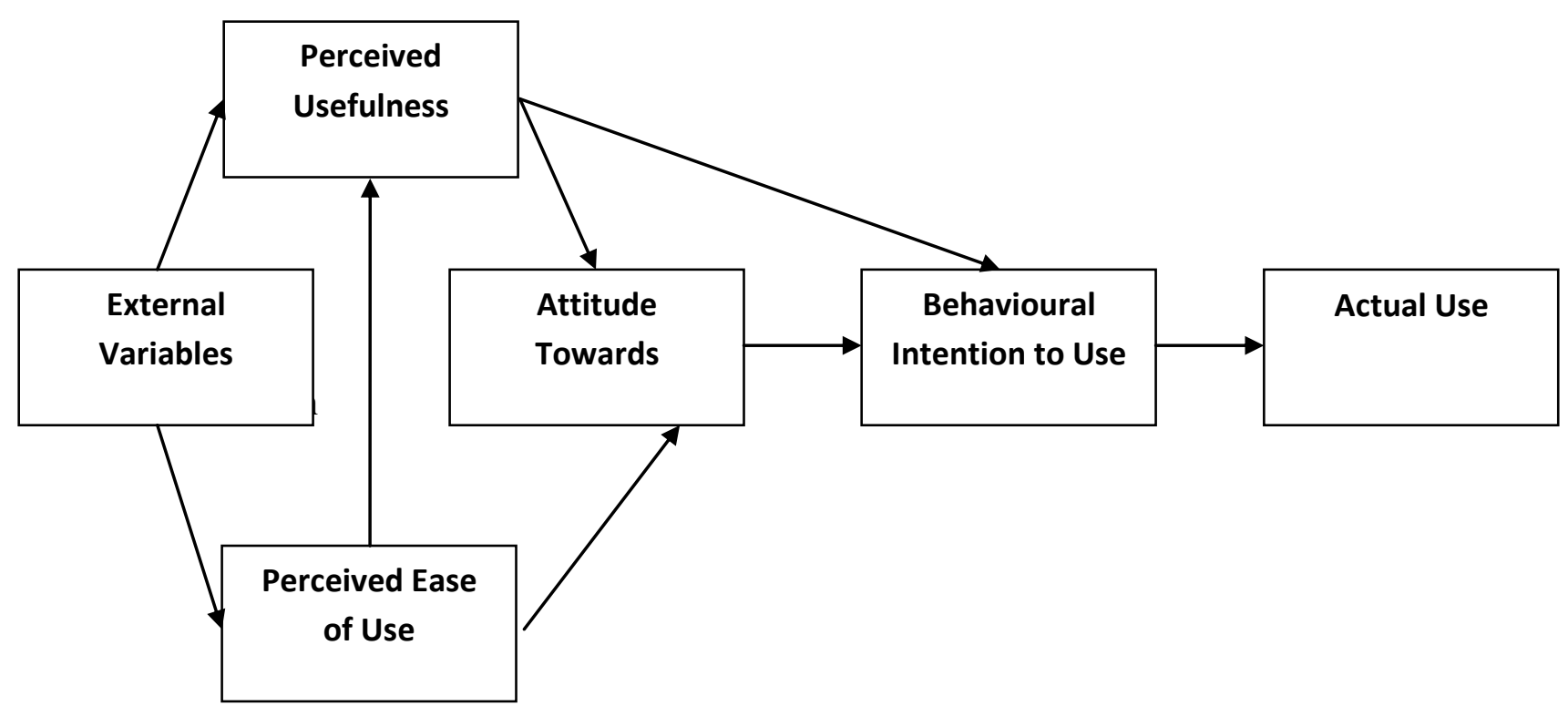

Source: Technology Acceptance Model (TAM) (Davis, 1989)

The model examined the external variables (usefulness and ease of use) which determined influence or attitude towards Information Technology (IT) utilisation (Dishaw \& Strong, 1999). The TAM theory was tailored to the study of user behaviour, and the context of 
information technology acceptance (Monday \& Turner, 2004). Furthermore, Masrom (2007) maintained that perceived ease of use and perceived usefulness of technology are determinants of user attitude towards technology, subsequent behavioural intentions and actual usage. In reality, perceived ease of use was also considered to influence perceived usefulness of the technology. Both perceived usefulness and perceived ease of use influences user's attitude towards technology utilisation.

This theory is relevant to the study as Perceived Usefulness (PU) relates to the impacts of Internet services and resources utilisation on academic activities of university lecturers in Adamawa State. The acceptance of the Internet technology and the resources forms the key. The technology needs to be accepted by the lecturers, use in order to impact on their academic activities.

\section{Methodology}

Survey research design was adopted and the target population for this study comprised of eight hundred and forty seven (847) lecturers in the three universities, namely; Adamawa State University Mubi (150), American University of Nigeria Yola (94) and Modibbo Adama University of Technology Yola (603). The table for determining sample size for a given population by Krejcie and Morgan (1970) was used to determine the sample size of 265 lecturers' in all the three universities. Stratified random sampling technique was used to obtain proportionate sample size from the faculties for all the three universities. The research instrument for this study was a self-designed questionnaire, where 4-point Likert's scale was used with 4- High, 3- Moderate, 2- Low, 1- Not Utilised for Utilisation, while 4Very high, 3- High, 2- Moderate, 1-Low used for impact. Data collected were analysed using descriptive statistics to answer the research question, and inferential statistics of Chisquare was used to test the formulated null hypothesis. The descriptive statistics showed the demographic characteristics of respondents (gender, age range, marital status, rank, highest educational qualification and faculty/school). Mean and Standard deviation were used to answer the level utilisation of Internet services and resources among university lecturers and also the impact of Internet services and resources on the teaching, research, communication, collaboration and publication output among university lecturers in Adamawa State, Nigeria. This statistics were adopted so as to obtain accurate results for the study. Statistical Package for Social Sciences (SPSS) tool, version 20.0 was used for the analysis.

Findings and discussion

Table 1: Response Rate

\begin{tabular}{ccccc}
\hline Universities & \multicolumn{2}{c}{$\begin{array}{c}\text { Questionnaire } \\
\text { Administered }\end{array}$} & \multicolumn{2}{c}{$\begin{array}{c}\text { Questionnaire } \\
\text { Returned }\end{array}$} \\
\cline { 2 - 5 } & $\mathbf{F}$ & $\mathbf{\%}$ & $\mathbf{F}$ & $\mathbf{\%}$ \\
\hline MAUTech, Yola & 189 & 71.2 & 178 & 67.2 \\
\hline
\end{tabular}


Impact of utilization of internet services and resources on university lecturers' academic activities in Adamawa state, Nigeria

\begin{tabular}{rcccc}
\hline ADSU, Mubi & 47 & 17.7 & 42 & 15.9 \\
AUN, Yola & 29 & 11.1 & 28 & 10.6 \\
\hline \multicolumn{1}{c}{ Total } & $\mathbf{2 6 5}$ & $\mathbf{1 0 0 . 0}$ & $\mathbf{2 4 8}$ & $\mathbf{9 3 . 7}$ \\
\hline
\end{tabular}

A total of 265 questionnaire were administered and 248 (93.7\%) were filled, returned and found usable for this study, with 42(15.9\%) from Adamawa State University, Mubi, while, American University of Nigeria and Modibbo Adama University of Technology, Yola were $28(10.6 \%)$ and $178(67.2 \%)$ respectively. The response rate followed directly according to the population of the lecturers in the universities investigated.

Table 2: Demographic Information of Respondents

\begin{tabular}{lll}
\hline Variables & Frequency & $\begin{array}{l}\text { Percentage } \\
(\mathbf{\%})\end{array}$ \\
\hline Gender & 165 & 66.5 \\
Male & 83 & 33.5 \\
Female & & \\
Age range & 32 & 12.9 \\
30-40years & 103 & 41.5 \\
41-49years & 83 & 33.5 \\
50-59years & 30 & 12.1 \\
60 years and above & & \\
& & \\
Marital status & 90 & 36.3 \\
Single & 158 & 63.7 \\
Married & & \\
Rank & & \\
Professors & 23 & 9.3 \\
Associate & 25 & 10.1 \\
Professors & & \\
Senior Lecturers & 44 & 17.7 \\
Lecturers I & 32 & 12.9 \\
Lecturers II & 73 & 29.4 \\
Asst. Lecturers & 51 & 20.6 \\
\hline Total & $\mathbf{2 3 5}$ & $\mathbf{1 0 0 . 0}$ \\
\hline
\end{tabular}

Out of 248 respondents, 165 (66.5\%) were males while 83 (33.5\%) were females. This implied that, male lecturers were more in terms of number than the female. Also, respondents who were between 31-40 were 32(12.9\%), 41 and 49years were 103 (41.5\%), 
while, $83(33.5 \%)$ of the lecturers were between 50 and 59 years. Only $30(12.1 \%)$ of the respondents were above 60 years. The selection could therefore be said to include all ages of the lecturers in the three universities. Also, majority of the respondents had their age range between 41 and 49 years which means that young men and women formed the bulk of lecturers in the three universities. The lowest respondents were $30(12.8 \%)$ with age range of 60 years and above respectively. Out of 248 Lecturers, 90 (36.3\%) were singles, while, 158 $(63.7 \%)$ were married. This shows that majority of the lecturers were married. Also, majority 73(29.4\%) of respondents were lecturers II, 51(20.6\%) were Assistant Lecturers, 32(12.9\%) were Lecturers I, 44(17.7\%) were Senior Lecturers, while, 25(10.1\%) were Associate professors and 23(9.3\%) were Professors.

Research Question: To what extent is the level of utilisation of Internet services and resources for university lecturers' academic activities in Adamawa State?

Table 3: Extent of Utilisation of Internet Services and Resources for University Lecturers' Academic Activities in Adamawa State

\begin{tabular}{|c|c|c|c|c|c|c|c|c|c|c|}
\hline \multirow{2}{*}{\multicolumn{2}{|c|}{$\begin{array}{l}\text { Internet Services and } \\
\text { Resources }\end{array}$}} & \multicolumn{9}{|c|}{ Extent of Utilisation of Internet Services and Resources } \\
\hline & & \multicolumn{2}{|c|}{ High } & \multicolumn{2}{|c|}{ Moderate } & \multicolumn{2}{|c|}{ Low } & \multicolumn{2}{|c|}{$\begin{array}{l}\text { Not } \\
\text { Utilised }\end{array}$} & \multirow[t]{2}{*}{ Remark } \\
\hline $\begin{array}{l}\text { S/ } \\
\mathbf{n} \\
\mathbf{o}\end{array}$ & $\begin{array}{l}\text { Internet Services and } \\
\text { Resources }\end{array}$ & FQ & $\%$ & FQ & $\%$ & FQ & $\%$ & FQ & $\%$ & \\
\hline 1 & E-mail services & 188 & $\begin{array}{c}80 . \\
0\end{array}$ & 32 & 13.6 & 11 & 4.7 & 4 & 1.7 & High \\
\hline 2 & File/document exchange & 22 & 9.4 & 180 & 76.6 & 21 & 8.9 & 12 & 5.1 & Moderate \\
\hline 3 & File Transfer Protocol (FTP) & 9 & 3.9 & 12 & 5.1 & 29 & $\begin{array}{c}12 . \\
3\end{array}$ & 185 & $\begin{array}{c}78 . \\
7\end{array}$ & Not Utilised \\
\hline 4 & Newsgroup & 16 & 6.8 & 27 & 11.5 & 11 & 4.7 & 181 & $\begin{array}{c}77 . \\
0\end{array}$ & Not Utilised \\
\hline 5 & Mailing lists & 6 & 2.6 & 14 & 6.0 & 192 & $\begin{array}{c}81 . \\
7\end{array}$ & 23 & 9.7 & Low \\
\hline 6 & World Wide Web (WWW) & 11 & 4.7 & 180 & 76.6 & 35 & $\begin{array}{c}14 . \\
9\end{array}$ & 9 & 3.8 & Moderate \\
\hline
\end{tabular}


Impact of utilization of internet services and resources on university lecturers' academic activities in Adamawa state, Nigeria

\begin{tabular}{|c|c|c|c|c|c|c|c|c|c|c|}
\hline 7 & Discussion group & 11 & 4.7 & 19 & 8.1 & 163 & $\begin{array}{c}69 . \\
4\end{array}$ & 42 & $\begin{array}{c}17 . \\
8\end{array}$ & Low \\
\hline 8 & $\begin{array}{l}\text { Frequently Asked Questions } \\
\text { (FAQ) }\end{array}$ & 21 & 8.9 & 9 & 3.8 & 46 & $\begin{array}{c}19 . \\
6\end{array}$ & 159 & $\begin{array}{c}67 . \\
7\end{array}$ & Not Utilised \\
\hline 9 & Search engines & 63 & $\begin{array}{c}26 . \\
8\end{array}$ & 138 & 58.7 & 14 & 6.0 & 20 & 8.5 & Moderate \\
\hline 10 & List Services & 8 & 3.4 & 11 & 4.7 & 31 & $\begin{array}{c}13 . \\
2\end{array}$ & 185 & $\begin{array}{c}78 . \\
7\end{array}$ & $\begin{array}{l}\text { Not } \\
\text { Utillised }\end{array}$ \\
\hline 11 & Chatting & 13 & 5.5 & 17 & 7.2 & 155 & $\begin{array}{c}66 . \\
0\end{array}$ & 50 & $\begin{array}{c}21 . \\
3\end{array}$ & Low \\
\hline 12 & Bulletin Board & 28 & $\begin{array}{c}11 . \\
9\end{array}$ & 15 & 6.4 & 21 & 8.9 & 171 & $\begin{array}{c}72 . \\
8\end{array}$ & Not Utilised \\
\hline 13 & E-books & 197 & $\begin{array}{c}83 . \\
8\end{array}$ & 23 & 9.8 & 11 & 4.7 & 4 & 1.7 & High \\
\hline 14 & Online Databases & 27 & $\begin{array}{c}11 . \\
5\end{array}$ & 193 & 82.1 & 11 & 4.7 & 4 & 1.7 & Moderate \\
\hline 15 & OPAC & 36 & $\begin{array}{c}15 . \\
3\end{array}$ & 164 & 69.8 & 11 & 4.7 & 24 & $\begin{array}{c}10 . \\
2\end{array}$ & Moderate \\
\hline 16 & E-journals & 175 & $\begin{array}{c}74 . \\
5\end{array}$ & 45 & 19.1 & 11 & 4.7 & 4 & 1.7 & High \\
\hline 17 & Conference Proceedings & 12 & 5.2 & 165 & 70.2 & 30 & $\begin{array}{c}12 . \\
7\end{array}$ & 28 & $\begin{array}{c}11 . \\
9\end{array}$ & Moderate \\
\hline 18 & E-theses & 16 & 6.8 & 166 & 70.6 & 39 & $\begin{array}{c}16 . \\
6\end{array}$ & 14 & 6.0 & Moderate \\
\hline
\end{tabular}

Table 3 above shows the extent of utilisation of Internet Services and Resources for University Lecturers' academic activities of the 235 Lecturers', with e-mail services (80.0\%), e-books $(83.8 \%)$ and e-journals $(74.5 \%)$ rated very high. The level of utilisation of search engine (58.7\%), File / Document Exchange (FDE) (76.6\%), World Wide Web (WWW) $(76.6 \%)$, online databases $(82.1 \%)$, OPAC $(100 \%)$, conference proceedings $(70.2 \%)$ and e-theses $(70.6 \%)$ were rated moderate. The level of utilisation of mailing list 
(81.7\%), discussion group (69.4\%) and chatting (66.0\%) were rated low, while, the level of utilisation of File Transfer Protocol (FTP) (78.7\%), Frequently Asked Question (FAQ) (67.7\%), list service (78.7\%), bulletin board (72.8\%) and news group (77.0\%) were not utilized. The overall analysis revealed that the extent of utilisation of Internet Services and Resources for University Lecturers' academic activities in Adamawa State was moderate.

\section{Hypothesis Testing}

Hypothesis H0: There is no significant difference in the impact of utilisation of internet services and resources, on academic activities of university lecturers' in Adamawa State. The study investigated the impact of utilisation of Internet services and resources on teaching, research, communication, collaboration and publication activities among university lecturers' in Adamawa State, Nigeria. The findings were presented in tables 4 below. 
Table 4: A cross tabulation of the observed and expected frequencies of the Differences in the Impact of Utilisation of Internet Services and Resources on Academic Activities of University Lecturers in Adamawa State.

\begin{tabular}{|c|c|c|c|c|c|}
\hline \multirow{2}{*}{$\begin{array}{l}\text { Impacts of Internet } \\
\text { Services and } \\
\text { Resources on } \\
\text { Academic Activities } \\
\text { of Lecturers }\end{array}$} & Very high & High & Moderate & Low & \multirow[t]{2}{*}{ Total } \\
\hline & $\begin{array}{l}F_{0} \\
F_{E}\end{array}$ & $\mathbf{F}_{0} \quad \mathbf{F}_{\mathbf{E}}$ & $\mathbf{F}_{\mathbf{0}} \quad \mathbf{F}_{\mathrm{E}}$ & $\mathbf{F}_{\mathbf{E}}$ & \\
\hline $\begin{array}{l}\text { Impact of the } \\
\text { Utilisation of Internet } \\
\text { Services and Resources } \\
\text { on Teaching Activities }\end{array}$ & $\begin{array}{l}65 \\
72\end{array}$ & $\begin{array}{l}93 \\
60\end{array}$ & $\begin{array}{l}77 \\
85\end{array}$ & $\begin{array}{l}00 \\
00\end{array}$ & $235(100)$ \\
\hline $\begin{array}{l}\text { Impact of the } \\
\text { Utilisation of Internet } \\
\text { Services and Resources } \\
\text { on Research Activities }\end{array}$ & $\begin{array}{l}100 \\
72\end{array}$ & $\begin{array}{l}52 \\
60\end{array}$ & $\begin{array}{c}49 \\
85\end{array}$ & $\begin{array}{l}34 \\
18\end{array}$ & $235(100)$ \\
\hline $\begin{array}{l}\text { Impact of the } \\
\text { Utilisation of Internet } \\
\text { Services and Resources } \\
\text { on Communication } \\
\text { Activities }\end{array}$ & $\begin{array}{l}109 \\
72\end{array}$ & $\begin{array}{l}56 \\
60\end{array}$ & $\begin{array}{l}49 \\
85\end{array}$ & $\begin{array}{l}21 \\
18\end{array}$ & $235(100)$ \\
\hline $\begin{array}{l}\text { Impact of the } \\
\text { Utilisation of Internet } \\
\text { Services and Resources } \\
\text { on Collaboration } \\
\text { Activities }\end{array}$ & $\begin{array}{l}19 \\
72\end{array}$ & $\begin{array}{l}56 \\
60\end{array}$ & $\begin{array}{l}160 \\
85\end{array}$ & $\begin{array}{l}00 \\
00\end{array}$ & $235(100)$ \\
\hline $\begin{array}{l}\text { Impact of the } \\
\text { Utilisation of Internet } \\
\text { Services and Resources } \\
\text { on Publication } \\
\text { Activities }\end{array}$ & $65 \quad 72$ & $\begin{array}{l}45 \\
60\end{array}$ & $\begin{array}{l}91 \\
85\end{array}$ & $\begin{array}{l}34 \\
18\end{array}$ & $235(100)$ \\
\hline
\end{tabular}

The null hypothesis formulated determined the significant impact in the utilisation of internet services and resources, on lecturers' academic activities in Adamawa State was tested using Chi-square $\left(\mathrm{X}^{2}\right)$ as follows: 
$\mathbf{H}_{\mathbf{0 1}}$ : There is no significant difference in the impact of utilisation of internet services and resources, on academic activities of university lecturers' in Adamawa State.

Table 5: 2x5 Chi-square contingency table for the test of the difference in the Impact of Utilisation of Internet Services and Resources on Academic Activities of University Lecturers in Adamawa State.

\begin{tabular}{|l|l|l|l|l|l|l|l|l|l|}
\hline Options & VH & $\mathbf{H}$ & $\mathbf{M}$ & $\mathbf{L}$ & Total & $\mathbf{X}^{\mathbf{2}}$ & Df & P-Value & $\begin{array}{l}\text { Decisio } \\
\mathbf{n} \\
\mathbf{P}<\mathbf{0 . 0 5}\end{array}$ \\
\hline Observed & 72 & 60 & 85 & 18 & $235(100)$ & 41.009 & 3 & 000 & $\mathrm{~s}$ \\
\hline Expected & 58.8 & 58.8 & 58.8 & 58.8 & $235(100)$ & & & & \\
\hline
\end{tabular}

\section{Significant At 0.05 Level of Significance.}

The result in table 5 shows that, the calculated $x^{2}$ is 41.009 , while, the p-value at 0.05 level of significance at 3 degree of freedom is 000 . Since the calculated $x^{2}$ of 41.009 is greater than the p-value of 000 at 0.05 level of significance with 3 degree of freedom, the null hypothesis which stated that, there is no Significant Difference in the Impact of Utilisation of Internet Services and Resources on Academic Activities of University Lecturers in Adamawa State is rejected. Therefore, this implies that there was significant impact of utilisation of Internet Services and Resources on academic activities of University Lecturers' in Adamawa State.

\section{Discussion}

The finding of this research revealed that the extent of utilisation of Internet services and resources for academic activities was generally moderate. However, the extent of utilisation of e-mail, e-books, online databases and e-journals were very high. This finding agrees with that of Nazim (2008) to some extent, the author established in a study that bulletin board services, discussion group, chatting, Frequently Ask Questions (FAQ), FTP, search engines and e-mail were the Internet services used by the respondents in the academic community for education and research purpose. The author did not rate the level of utilisation as done by the researcher and bulletin board service was not used by Lecturers' for their academic activities in the universities studied. As noted by Al-ansari (2006) the level of Internet services and resources utilisation varies from individual to individual, institution to institution and country to country. The study further revealed that Internet services and resources were used for the purposes of communication, research, publication, finding of current information and cooperation with colleagues. This finding corroborates that Ajala, Adegun and Oyewunmi (2010) which revealed the utilisation of e-mail and Internet services by academic staff of Ladoke Akintola University, Nigeria, was high. The finding was also in line with the study by Ukpebor (2011). The author asserted that e-mail was the most preferred Internet service among engineering lecturers and students of the Edo 
State University, Nigeria.

The study shows that impacts of the utilisation of Internet services and resources on academic activities were generally moderate. However, there was very high impact on research and communication activities. The study agreed with the study conducted by Ajala, Adegun \& Oyewunmi (2010) that revealed that the Internet was found to be useful for research activities, however it was not utilised for effective teaching and learning purposes.

\section{Conclusion and recommendations}

Based on the findings of this study, the impact of Internet services and resources on academic activities in Adamawa State universities remained moderate. This was as a result of moderate level of utilisation of Internet services and resources. Utilization of e-mail, ejournals and e-books and was very high. However, there was moderate utilization of search engine, File / Document Exchange (FDE), World Wide Web (WWW), online databases, OPAC, conference proceedings and e-theses. Utilisation of mailing list, discussion group and chatting was low, while, File Transfer Protocol (FTP), Frequently Asked Question (FAQ), list service, bulletin board and news group were not utilized, and this had affected the overall impact of Internet services and resources on academic activities. Utilisation of Internet services and resources had very high impact on research and communication of lecturers in Adamawa State Universities. However, utilisation of Internet services and resources had moderate impact on teaching, collaboration and publication activities of the lecturers. It is recommended that the Universities should engage in sensitization, demonstrations and training workshops for lecturers on the use and benefits of utilisation of Internet services and resources for academic activities. Academic staff should be educated on the use of Internet services and resources for academic activities. To increase the impact of utilisation of Internet services and resources on academic activities, lecturers should be encouraged to use Internet services and resources for collaboration and publication activities, especially online publications.

\section{References}

Adams, D. A, Nelson, R. R \& Todd, P. A (1992). Perceived usefulness, ease of use and usage of information technology: a replication. MIS Quarterly, 16 (2), 227-247.

Adekunmisi, S. R., Ajala, E. B. \& Iyoro, A.O. (2013). Internet access and usage by students: a case study of Olabisi Onabanjo University, Nigeria. Library Philosophy and Practice (e-journal), 848. Retrieved from http://digitalcommons.unl.edu/libphilprac

Adika, G. (2003). Internet use among faculty members of universities in Ghana. Library Review, 52 (1), 29-37. 
Ajala, I. O., Adegun, A. I., Adetunji, A. \& Oyewunmi, O. O. (2010).The impact of internet use on teaching and research by Ladoke Akintola University of Technology (LAUTECH) academic staff. Information Technologist, 7 (2), 188-194.

Al-Ansari, H. (2006). Internet use by the faculty members of Kuwait university. The Electronic Library, 24 (6), 791- 803.doi: 10.1108/02640470610714224

Al-Asmari, A. M. (2005). The use of the internet among EFL teachers at the colleges of technology in Saudi Arabia. Information, Knowledge, Systems Management, 5, 227-243.

Alshare, K. A. \& Alkhateeb, F. B. (2008). Predicting students' usage of internet in two emerging economics using an extended technology model (TAM). Academy of Educational Leadership Journal, 12 (2), 109-128.

Asemi, A. (2005). Information searching habits of internet users: a case study on the medical sciences university of Isfahan, Iran. Webology, 2 (1). Retrieved from http://www.webology.ir/2005/v2n1/a10.html

Arthur, C. \& Brafi, P.O. (2013).Internet use among students in tertiary institutions in the Sunyani municipality, Ghana. Library Philosophy and Practice (e-journal), 859. Retrieved from http://digitalcommons.unl.edu/libphilprac

Bassi, M. D. \& Camble, E. (2011).Gender difference in use of electronic resources in university libraries of Adamawa State, Nigeria. Library philosophy and Practice (ejournal), 549. Retrieved from http://digitalcommons.unl.edu/libphilprac

Dangani, U.B. \& Mohammed, Z. (2009).Information and communication technology literacy among academics in Ahmadu Bello University Zaria. Samaru Journal of Information Studies, 9 (2).

Davis, F. D. (1989). Perceived usefulness, received ease of use, and user acceptance of information technology. MIS Quarterly, 13 (3), 319-339.

Dishaw, M.T. \& Strong, D.M. (1999). Extending the technology acceptance model with task-technology fit constructs. Information and Management, 36, 9-12.

Eyitayo, O.T. (2008). Internet Facilities and the Status of Africa's connectivity. In In Aina, L.O., Mutula, S.M., \& Tiamiyu, M.A. (Eds.), Information and knowledge management in the digital age: Concepts, technologies and African perspectives. Ibadan: Third World Information Service: 2- 41.

Gakibayo, A, Ikoja-Odongo, J.R \& Okello - Obura, C. (2013). Electronic Information 
Impact of utilization of internet services and resources on university lecturers' academic activities in Adamawa state, Nigeria

resources utilisation by students in Mbarara University Library Library philosophy and Practice (e-journal), 869. Retrieved from http://digitalcommons.unl.edu/libphilprac

Hendrickson, (1993). On the test- retest reliabiality of perceived usefulness and perceived ease of use scales. MIS Quarterly, (17) $227-230$.

Hinson, R.E .(2011). Internet browsing behaviour: a case study of executive postgraduate students in Ghana. Information Development, 27 (3), $176-185$. doi: $10.1177 / 0266666911414382$

Kamba. M. A. (2008). The changing role of researchers in Nigeria: the internet as an alternative future to modernity. Library philosophy and Practice (e-journal), 229. Retrieved from http://digitalcommons.unl.edu/libphilprac

Konana, P. \& Balasubramanian, S. (2005). The Social - economis - psychological model of technology adoption usage: an application to online investing. Decision Support System, 39(3), $505-524$.

Krejcie, R. V. \& Morgan, D. W. (2006). Determining sample for research activities: Educational and Psychological measurement.

Lawal, E. O. S. (2013) The Use of Information and Communication Technology (ICT) in Academic Libraries in Nigeria: A Case Study of Covenant University Library Ota, Nigeria. Journal of Library and Information Science (JOLIS), $10(1 \& 2, P P$.

Madu, E. C. (2008) Fundamentals of modern reference services: Manual vs Electronic. Ibadan: Evi-coleman Publications.

Manda, P.A. (2005). Electronic resource usage in academic and research institutions in Tanzania. Information Development, 21 (4), 269-282.

Masrom, M. (2007). Technology acceptance model and e-learning.12 $2^{\text {th }}$ International Conference on Education, Sultan HassanalBolkiah Institute of Education.Universiti Brunei Darussalam.

Monday, W. \& Turner, A. (2004).Application of the Technology Acceptance Model to Knowledge Management System. In Sprague, R.H. Jr. (ed), Proceedings of Ife $37^{\text {th }}$ Annual Hawaii International Conference on System Sciences, January 5-8, Kona, Hawaii.

Nazim, M. (2008). Information searching behaviour in the internet ages a users` study of Aligarh Muslim University. The International Information \&Library Review, 40, 73-81. doi:10.1016/j.iilr.2007.11.001 
Nwezeh, C (2010). The Use of ICT in Nigeria Universities: A Case study of Obafemi Awolowo University, Ile-Ife. Available at www.webpages.uidaho.edu/ mbolin/nwezeh.htm. (Accessed January 11, 2013).

Ogunjobi, T. E., \& Fagbami, O. O.(2012).Use of the internet by researchers in agricultural research institute in Ibadan, Oyo state. International Journal of Library and Information Science, 4 (4), 52-56.doi:10.5897/IJLIS11.068

Okello-Obura, C. \& Magara, E. (2008).Electronic information access and utilisation by Makerere university students in Uganda.Evidence Based Library and Information Practice, 3 (3), 39-51. Retrieved from http://ejournals. library.ualberta.ca.

Oniyide, D.B. (2005) The Internet and World Wide Web as Resources for Teaching and Learning in schools. Ibadan: Macmillan.

Opeke, R.O. \& Odunlade, R.O. (2011).Awareness and utilisation of information resources among polytechnic lecturers in Nigeria.Samaru Journal of information Studies, 11 (1\&2), 59-66.

Parent, I. \& Cruickshark, N. (2009).The growth of the internet and knowledge networks, and their impact in developing world. Information Development, 25 (2), 99-98. doi:10.1177/026666909104709.

Park, S. Y. (2009). An Analysis of the technology acceptance model in understanding university students' behavioral intention to use e-learning. Educational Technology \& Society, 12 (3), 150-162.

Shroff, R. H. Deneen, C. C. \& Eugenia M. W. (2011) Analysis of the technology acceptance model in examining students' behavioural intention to use an e-portfolio system. Australasian Journal of Educational Technology, 27(4), 600-618.

Szajna, B. (1994). Software evolution and choice: predictive evolution of the Technology Acceptance Instrument. MIS Quarterly, 18(3), 318 - 324.

Ukpebor, C. (2011). A survey of internet use by lecturers and students in engineering faculties in Edo State, Nigeria. Nigerian Libraries, 44(2), 58-74.

Dr. Tukur Abba is of the Ibrahim Babangida Library, Modibbo Adama University of Technology, P.M. B 2076, Yola, Nigeria.He can be reached at tukurabba@mautech.edu.ng 